\title{
CONVENTIONAL AGEING AND SEXING METHODS BASED ON TEETH AND DRY BONE MORPHOLOGY IN THE PERSON'S IDENTIFICATION (VICTIMS OF RED TERROR IN 1946)
}

\author{
Raili Allmäe, Jana Limbo-Simovart \\ Institute of History, Tallinn University
}

\begin{abstract}
Human skeletal remains exhumated from the post-war multiple grave in Souhthern Estonia were anthropologically analysed. Conventional ageing and sexing methods were used to esimate biological sex and age at death of buried people. The blind test was carried out by two independent researchers; the obtained results were compared with historic data concerning the chronological age at death and the sex of buried people.
\end{abstract}

Keywords: ageing techniques, forensics, osteology, human bones, forensic archaeo$\log y$

\section{INTRODUCTION}

In 2012 a military archaeologist asked us, the physical anthropologists, to study the human skeletal remains recovered from the grave at the Hindriku Farm, Southern Estonia.

On 1 April 1946 a famous battle between NKVD (KBG) and Forest Brothers took place in Southern Estonia. Six people were fighting against NKVD forces at the Hindriku farm. Forest Brothers did not surrender and all of them fell in the burning house [1]. According to historic data and eyewitnesses the names of five victims out of six were known. After the battle badly burned bodies of four men and two women were carried out of the house and buried at the premices of the Hindriku Farm. 
The purpose of the anthropological investigation was to estimate the age at death and the biological sex of buried individuals in order to indentify the buried individuals by the help of conventional ageing and sexing methods. Rarely biological anthropologists have a possibility to compare their age and sex estimations based on skeletal remains with the actual chronological age of individuals. We decided to conduct a blind test in order to get some feedback on our ageing technique. Therefore, we asked not to provide us with the birth data of the buried individuals. Two anthropologists separately carried out biological sex and age at death estimations using common methodology. Thus, the second purpose of our study was to compare these blind test results with historic data - plausible known sex and the chronological age of individuals in order to find out do these data overlap/correlate.

\section{MATERIAL AND METHODS}

\section{Material}

The material consisted of six partial skeletons exhumated from the multiple grave from 1946. In most cases the cranial parts of skeletons were absent likewise the distal parts of upper and lower extremities; only two individuals had some teeth present. All skeletons indicated burning marks. The preservation of skeletons, all injuries and burning marks on bones were recorded (written report, the drawings of skeletons, photos and videos).

\section{Methods}

Biological sex estimations based on human skeletal remains were conducted according to morphological descriptive features described in common standards $[5,13]$. The osteometric features were used for sexing skeletons also: vertical diameter of the femoral head and the circumference of the femoral head [ 2 and references in it).

Biological age estimation was conducted according to the following methods:

- The surface of pubic symphysis after Brooks and Suchey [3]

- The surface of pubic symphysis after Todd [12]

- The auricular surface of the ilium scoring system after Buckberry and Chamberlain [4]

- The morfology of the auricular surface of the ilium after Lovejoy and colleagues [10]

- The morphology of sternal rib ends after Isçan and colleagues [6,7] 
- Periodontosis and translucency of the tooth root after Lamendin and colleagues [9]

Two individuals had some teeth preserved, but the ageing technique worked out by Lamendin and colleagues (1992) could be used only on one skeleton. Our age estimations were mostly based on five methods, which follow morphological changes on pubic symphysis, the auricular surface of the ilium and on sternal rib ends. The minimum and maximum values of age estimations as well the average based on six methods is presented for every skeleton. Age classes proposed by Buikstra and Ubelaker (1994) were also used.

\section{RESULTS AND DISCUSSION}

The results of age and sex estimations are presented in Table 1. Two female and four male skeletons were identified amongst skeletal material. According to the age classes proposed by Buikstra and Ubelaker [4] four skeletons were categorized in the age class young or middle adult (20-35/35-50 years), one in the border of adolescent and young adult (12-20/20-35 years) and one in the age class of middle to old adult (35-50/50+ years).

Table 1. The results of biological sex and age estimations range according to six methods (in years)

\begin{tabular}{lccccccc}
\hline & $\begin{array}{c}\text { Buikstra, } \\
\text { Ubelaker } \\
1994\end{array}$ & $\begin{array}{c}\text { Lamendin } \\
\text { et al 1992 }\end{array}$ & $\begin{array}{c}\text { Brooks, } \\
\text { Suchey } \\
1990\end{array}$ & Todd 1920 & $\begin{array}{c}\text { Lovejoy } \\
\text { et al } \\
1985\end{array}$ & $\begin{array}{c}\text { Buckberry/ } \\
\text { Chamber- } \\
\text { lain 2002 }\end{array}$ & $\begin{array}{c}\text { Iscan } \\
1985\end{array}$ \\
\cline { 2 - 8 } & $\begin{array}{c}\text { Skeletal } \\
\text { morphology }\end{array}$ & $\begin{array}{c}\text { Dental } \\
\text { age }\end{array}$ & $\begin{array}{c}\text { Pubic } \\
\text { symphysis }\end{array}$ & $\begin{array}{c}\text { Pubic } \\
\text { symphysis }\end{array}$ & $\begin{array}{c}\text { Auricular } \\
\text { surface }\end{array}$ & $\begin{array}{c}\text { Auricular } \\
\text { surface }\end{array}$ & $\begin{array}{c}\text { Sternal } \\
\text { rib ends }\end{array}$ \\
\hline $\begin{array}{l}\text { Indi- } \\
\text { vidual }\end{array}$ & & & & Observer 1 & & & \\
\hline I & female & 33.66 & 38.2 & $30-35$ & $35-39$ & 51.41 & $33.7-46.3$ \\
\hline II & female & - & $48.1-60.0$ & $39-50$ & - & 59.94 & - \\
\hline III & male & - & 28.7 & $27-30$ & $25-34$ & 37.86 & $24.1-30.6$ \\
\hline IV & male & - & 28.7 & $30-35$ & $25-34$ & 37.86 & $20.8-23.1$ \\
\hline V & male & - & 18.5 & $18-19$ & - & 17.33 & $16.5-18$ \\
\hline VI & male & - & 35.2 & $35-39$ & - & 29.33 & $25.7-30.6$ \\
\hline
\end{tabular}




\begin{tabular}{lccccccc}
\hline & $\begin{array}{c}\text { Buikstra, } \\
\text { Ubelaker } \\
1994\end{array}$ & $\begin{array}{c}\text { Lamendin } \\
\text { et al 1992 }\end{array}$ & $\begin{array}{c}\text { Brooks, } \\
\text { Suchey } \\
1990\end{array}$ & Todd 1920 & $\begin{array}{c}\text { Lovejoy } \\
\text { et al } \\
1985\end{array}$ & $\begin{array}{c}\text { Buckberry/ } \\
\text { Chamber- } \\
\text { lain 2002 }\end{array}$ & $\begin{array}{c}\text { Iscan 1984; } \\
1985\end{array}$ \\
\cline { 2 - 8 } & $\begin{array}{c}\text { Skeletal } \\
\text { morphology }\end{array}$ & $\begin{array}{c}\text { Dental } \\
\text { age }\end{array}$ & $\begin{array}{c}\text { Pubic } \\
\text { symphysis }\end{array}$ & $\begin{array}{c}\text { Pubic } \\
\text { symphysis }\end{array}$ & $\begin{array}{c}\text { Auricular } \\
\text { surface }\end{array}$ & $\begin{array}{c}\text { Auricular } \\
\text { surface }\end{array}$ & $\begin{array}{c}\text { Sternal } \\
\text { rib ends }\end{array}$ \\
\hline $\begin{array}{l}\text { Indi- } \\
\text { vidual }\end{array}$ & & & & Observer 2 & & & \\
\hline I & female & 37.2 & $30.7-38.2$ & $27-35$ & $30-34$ & - & $24.4-31.0$ \\
\hline II & female & - & $48.1-60.0$ & $44-50+$ & $44-59$ & 59.94 & - \\
\hline III & male & - & 28.7 & $25-30$ & $30-34$ & 29.33 & $34.4-42.3$ \\
\hline IV & male & - & 23.4 & $25-30$ & $25-29$ & $17.33-$ & 29.33 \\
\hline V & male & - & 18.5 & $18-19$ & $20-24$ & - & $16.5-18.0$ \\
\hline VI & male & - & 28.7 & $30-35$ & $35-39$ & - & $25.7-30.6$ \\
\hline
\end{tabular}

The age and sex estimations were compared to the chronological age and sex of individuals known from historic data (Table 2; Figures 1,2). According to eyewitnesses and the oral data the identity of five people who died at the Hindriku Farm was known [1]. Two women, one at the age of 48, and the second one at the age of 72 died in the burning house. The identity of three men at the farm was also known (age at death 34, 32 and 25 years respectively), but the fourth man was unknown (to be more precise, two different persons are proposed).

Our results confirm the sex composition of individuals who died at the farm. The age composition is much more difficult to interpret. We found that one woman was younger than the other, but the estimated age and chronological age do not overlap in both cases. According to the anthropological analyses of two researchers the younger women was aged between 30-40 years at the time of death, and the older women around 50 years (Table 2; Figures 1,2). The skeletal age around 50 years is in correlation with historic data, but the estimated skeletal age of the younger woman (30-40 years) does suit in the picture.

The most probable reasons for discrepancy between chronological and estimated age could be methodological ones. Many researchers have argued that the age of older individuals (older than 50 years) is much more difficult to estimate, because many ageing techniques are useful beyond this age class $[8,11]$. Our data confirm this argument (Table 2; Figures 1,2), as individuals under 35 years of age were positively identified by the conventional ageing methods (male skeletons III, IV and VI). 
Table 2. The calculated average age at death and the chronological (real) age of individuals (in years)

\begin{tabular}{ccccc}
\hline \multicolumn{5}{c}{ Observer 1 } \\
\hline Number/ Age & min & max & average & real \\
\hline I & 30.0 & 51.4 & 40.7 & 48 \\
\hline II & 39.0 & 60.0 & 49.5 & 72 \\
\hline IV & 24.1 & 37.9 & 31.0 & 34 \\
\hline V & 20.8 & 37.9 & 29.3 & 25 \\
\hline VI & 16.5 & 19.0 & 17.8 & $?$ \\
\hline VI & 25.7 & 39.0 & 32.4 & 32 \\
\hline Number/ Age & min & max & average & real \\
\hline I & 24.4 & 38 & 31.3 & 48 \\
\hline II & 44.0 & 60 & 52.0 & 72 \\
\hline III & 25.0 & 42 & 33.7 & 34 \\
\hline IV & 17.3 & 30 & 23.7 & 25 \\
\hline V & 16.5 & 24 & 20.3 & $?$ \\
\hline VI & 25.7 & 39 & 32.4 & 32 \\
\hline
\end{tabular}

Methodological issues could explain the relatively young skeletal age of the older woman (skeleton II), but do not explain the discrepancy between of the estimated and the chronological age of the younger woman (skeleton I). The skeleton of the younger woman (skeleton I) had some teeth present, both observers estimated her dental age also below 40 years (table 1).

We cannot completely rely on historic data also, because it could contain false assumptions regarding the identity of the people who died at the Hindriku Farm.

"The estimation of age at death of adult skeletal material is one of the more difficult tasks undertaken by physical anthropologists" [4]. The rates of skeletal ageing and degeneration vary between individuals and populations [11], and are very difficult to standardise. The reason is that people are ageing differently and there is not always correlation between the biological skeletal age and the chronological one. In the light of these conclusions our results of skeletal 
ageing can be definitely verified or disclaimed, when the exhumed skeletal remains are positively identified by the methods of molecular genetics.

\section{Observer 1}

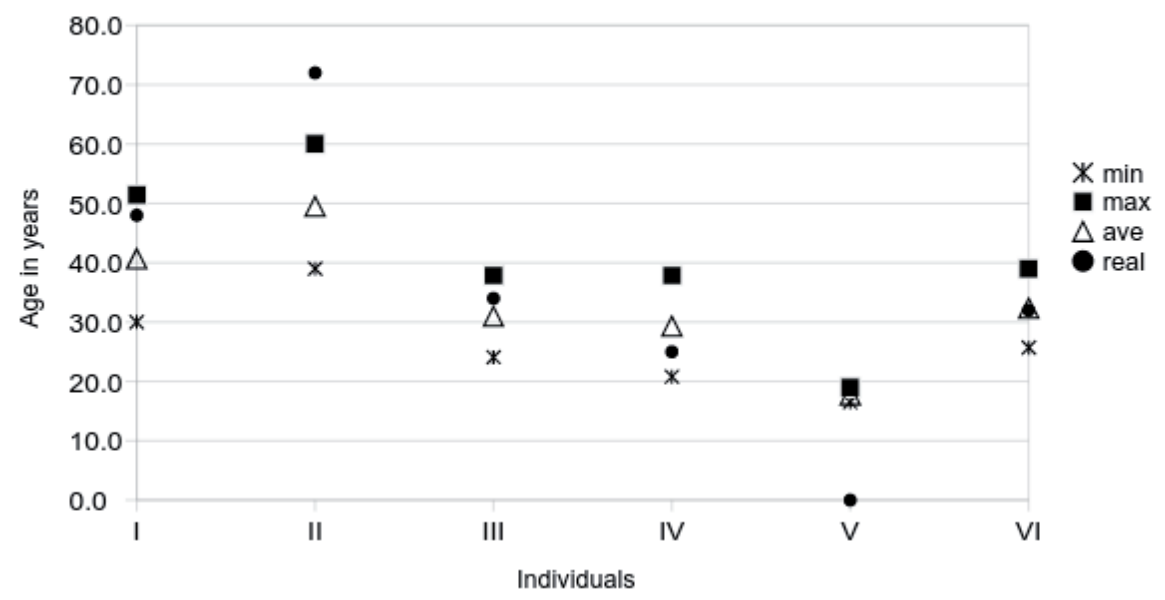

Figure 1. Age estimation results of observer 1.

\section{Observer 2}

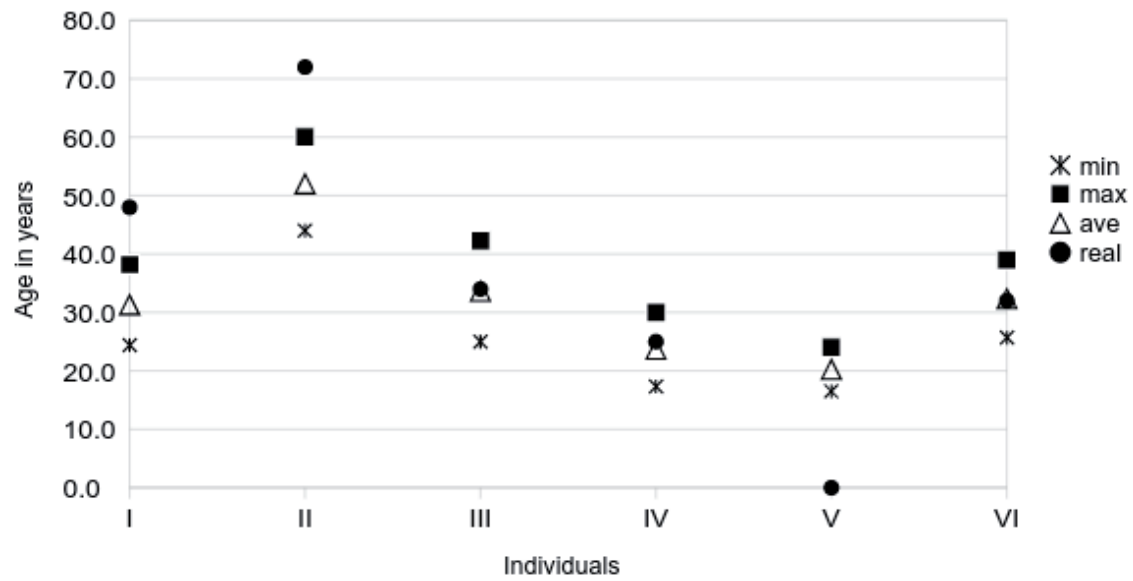

Figure 2. Age estimation results of observer 2 . 


\section{CONCLUSIONS}

The age and sex of the three individuals buried at the premises of Hindriku were positively identified with conventional ageing and sexing methods: males at the ages 31-34 years, 24-29 years and the last around 32 years of age at death. The results overlap with historically known birth data of these men. The identity of the fourth male was not known, but he was 18-20 years old at the time of death.

Two female skeletons were identified amongst skeletal material. The ageing of female skeletons was complicated. Physical anthropologists found that one skeleton belongs to the woman 30-41 years old and the second woman died around 49-52 years of age. According to historic data two women died in the fire at the Hindriku Farm, the first was 48 and the second 72 years old at their time of death. No precise overlap between skeletal and historically known age at death was found.

Our results of ageing and sexing the skeletal material with conventional methods showed that the positive indentification is more likely in the case of younger individuals, whose age is beyond 35 years at the time of death.

\section{REFERENCES}

1. Aarop K. (2008). Lahing Hindriku talus. Kultuur ja Elu 2, 49-52. http://kultuur.elu.ee/index_ke492.htm

2. Bass W. (2005). Human Osteology: A Laboratory and Field Manual. Missouri.

3. Brooks S.T., Suchey J.M. (1990). Skeletal Age Determination Based on the Os Pubis: A Comparison of the Acsadi-Nemeskeri and Suchey-Brooks Methods. Human Evolution, 5, 227-238.

4. Buckberry J.L., Chamberlain A.T. (2002). Age estimation from the auricular surface of the ilium: a revised method. American Journal of Physical Anthropology, 119, 231-239.

5. Buikstra J.E., Ubelaker D. (eds.) (1994). Standards for Data Collection from Human Skeletal Remains: Proceedings of a Seminar at the Field Museum of Natural History. Fayetteville.

6. Işcan M.Y., Loth S.R., Wright R.K. (1984). Age estimation from the rib by phase analysis: white males. Journal of Forensic Science, 29, 4, 1094-104.

7. Işcan M.Y., Loth S.R., Wright R.K. (1985). Age estimation from the rib by phase analysis: white females. Journal of Forensic Science, 30, 3, 853-63.

8. Iscan M.Y., Steyn M. (2013). The Human Skeleton In Forensic Medicine. 3rd edition. C.C. Thomas Publisher, Springfield. 
9. Lamendin H., Baccino E., Humbert J.F., Tavernier J.C., Nossintchouk R.M., Zerilli, A. (1992). A simple technique for age estimation in adult corpses: the two criteria dental method. Journal of Forensic Science, 37, 5, 1373-1379.

10. Lovejoy C.O., Meindl, R.S., Pryzbeck, T.R., Mensforth, R.P. (1985). Chronological metamorphosis of the auricular surface of the ilium: a new method for the determination of adult skeletal age at death. American Journal of Physical Anthropology, 68, 1, 15-28.

11. Mays S. (1998). The Archaeology of Human Bones. Routledge. London.

12. Todd T.W. (1920). Age Changes in the Pubic Bone, I: The Male White Pubis. American Journal of Physical Anthropology, 3, 285-34.

13. White T.D., Folkens, P.A. (2000). Human Osteology. 2nd edition. Academic Press, San Diego CA.

\section{Address of correspondence}

Raili Allmäe

Institute of History

Tallinn University

Rüütli 6, Tallinn 10130, Estonia

E-mail: rallmae@gmail.com 